\title{
Serum level of transforming growth factor- beta1 in major idiopathic interstitial pneumonia
}

\author{
Mohamed W. Zakaria', Reem I. El-Korashy', Samah Selim"(D), Ingy Badawy² and Kwashi J. Amum³
}

\begin{abstract}
Background: Different inflammatory cytokines play a role in the mechanism and pathogenesis of fibrosis in idiopathic interstitial pneumonia (IIP). Transforming growth factor-beta1 (TGF- $\beta 1$ ) has become a subject of interest. The aim of the work is to measure the serum level of TGF- $\beta 1$ in different forms of major IIP and to find out its relation to the patients' clinical and arterial blood gases' parameters.

Results: The patients' group showed significant elevation of serum level of TGF- $\beta 1$ in comparison with the control group ( $P$ value $<0.001$ ). In patients with IPF, the serum level of TGF- $\beta 1$ was not significantly increased compared to patients with other forms of major IIP (mean $\pm S D=300 \pm 84.52$ versus $340 \pm 131.20 \mathrm{pg} / \mathrm{ml}, P$ value $=0.32$ ). There was an inverse negative correlation between the age and serum level of TGF- $\beta 1$ ( $r=-0.39 ; P=0.03)$. An inverse non-significant correlation was found between the serum level of TGF- $\beta 1$ and the dyspnoea score $(r=-0.30, P=$ 0.11). However, there was a significant positive correlation between the serum level of TGF- $\beta 1$ and the distance of 6 -MWT ( $r=0.44 ; P=0.02)$. It was also found that there was a positive correlation between the serum level of TGF- $\beta 1$ and both arterial oxygen pressure $\left(\mathrm{PaO}_{2}\right)(r=0.39, P=0.03)$ and arterial oxygen saturation $(r=0.33, P=0.07)$.
\end{abstract}

Conclusion: Serum level of TGF- $\beta 1$ is elevated in patients with IIP and it positively correlated to both 6-MWD and $\mathrm{PaO}_{2}$. Further larger studies are needed to evaluate its prognostic value.

Keywords: Idiopathic interstitial pneumonia, Lung fibrosis, Six-minute walk test, Transforming growth factor-beta1

\section{Background}

Idiopathic interstitial pneumonias (IIP) are interstitial lung diseases (ILD) of unknown aetiology that have similar clinical and radiological features. They differ primarily by the histological patterns on lung biopsy $[1,2]$.

Transforming growth factor beta1 is a multifunctional peptide that controls proliferation, differentiation of many cells. It is considered one of the profibrotic cytokines and it is produced in the lung by many cell types including alveolar macrophages, neutrophils, activated alveolar epithelial cells, fibroblast and myofibroblasts [3].

\footnotetext{
* Correspondence: samah.selim@ymail.com

'Department of Chest Diseases, Faculty of Medicine, Cairo University, Cairo, Egypt

Full list of author information is available at the end of the article
}

The potential importance of TGF- $\beta 1$ in the pathogenesis of IIP is suggested by studies showing high levels of serum TGF- $\beta 1$ are associated with increased fibrosis $[4,5]$.

The aim of the study was to measure the serum level of TGF- $\beta 1$ in IIP and to find out its relation to the clinical parameters, including age, sex, dyspnoea score and distance of six-minute walk test (6-MWT).

\section{Methods}

A prospective case-control study that was carried out at the Chest Department, Kasr Al-Ainy Hospital, Cairo University, in collaboration with the Pharmaceutical Biotechnology Department between February 2016 and April 2017. Thirty patients with major IIP were included

\section{Springer Open}

(ㅇ The Author(s). 2020 Open Access This article is licensed under a Creative Commons Attribution 4.0 International License, which permits use, sharing, adaptation, distribution and reproduction in any medium or format, as long as you give appropriate credit to the original author(s) and the source, provide a link to the Creative Commons licence, and indicate if changes were made. The images or other third party material in this article are included in the article's Creative Commons licence, unless indicated otherwise in a credit line to the material. If material is not included in the article's Creative Commons licence and your intended use is not permitted by statutory regulation or exceeds the permitted use, you will need to obtain permission directly from the copyright holder. To view a copy of this licence, visit http://creativecommons.org/licenses/by/4.0/. 
in the study: fifteen patients with idiopathic pulmonary fibrosis and 15 patients with other forms of major IIP.

They were diagnosed based on a multidisciplinary review of the clinical, radiological and pathological data according to the guidelines of the international consensus statement produced as a collaborative effort from the American Thoracic Society and European Respiratory Society Guidelines 2013 [2]. Twenty healthy individuals were included as a control group.

This human study was approved by the ethical committee of the Faculty of Medicine, Cairo University. All adult participants provided written informed consent to participate in the study.

All patients were subjected to the following:

1. Thorough history taking and clinical examination including; age, sex, smoking status, modified Medical Research Council scale (mMRC) for dyspnoea.

2. Spirometry: It was performed using master screen Jager-D 97204 Hochberg Germany.

Manoeuvre of the flow volume loop:

- Calibration of the system was done each time.

- Explanation of the procedure to each patient.

- The nose was clipped by the nose clip and the patient was connected to the mouthpiece.

- Every patient was instructed to breathe tidally for several times then to inhale slowly till total lung capacity (TLC), then to exhale forcibly as much as possible.

- The procedure was repeated three times and the best result was selected according to forced vital capacity (FVC) and forced expiratory volume in the $1^{\text {st }}$ second (FEV1) [6].

The following data were obtained and interpreted:

Measurement of the $\mathrm{FEV} 1 \%$ predicted, $\mathrm{FVC} \%$ predicted, FEV1/FVC\% and forced expiratory flow (FEF25$75 \%$ predicted). The presence of an FEV1/FVC $>0.70$ together with $\mathrm{FVC}<80 \%$ predicated confirm the presence of restriction.

The severity of restriction was determined according to the results of FVC as follows [6]: mild restriction, FVC $60-80 \%$; moderate, FVC $40-59 \%$; and severe restriction, FVC less than $40 \%$.

\section{Six-minute walk test (6-MWT)}

Every patient was instructed to wear his/her comfortable footwear. The patient's usual medication should be continued and the patient should not have exercised vigorously within $2 \mathrm{~h}$ before the beginning of the test.
Measurement of the distance walked as far as possible for $6 \mathrm{~min}$ [7].

\section{Measurement of arterial blood gases $\left(\mathrm{ABG}_{\mathrm{s}}\right)$}

One millilitre of arterial blood was obtained from the radial artery in a heparinized needle and then taken immediately to a blood gas analyzer ( $\mathrm{pHOx}$ plus $\mathrm{C}$ ) to assess the $\mathrm{PH}, \mathrm{PaO}_{2}, \mathrm{PaCO}_{2}$ and $\mathrm{SaO}_{2}$. Calculation of alveolar-arterial oxygen pressure difference (PA$\mathrm{aO}_{2}$ ) was carried out.

\section{Measurement of serum level of TGF- $\beta 1$ Serum collection and preparation}

Three millilitres of blood sample was taken from each person and poured into a clot tube, and the coagulated serum sample was separated by centrifugation and then stored at $-20{ }^{\circ} \mathrm{C}$ in a 0.5 -cc vial. After collection of samples, usage of enzyme-linked immunosorbent assay (ELISA) kits (DRG TGF- $\beta 1$ ELISA Kits, International Inc., USA) was performed.

\section{Principles of the test}

The DRG TGF- $\beta 1$ ELISA Kit is a solid phase enzymelinked immunosorbent assay (ELISA) based on the sandwich principle.

Prior to testing, the standards and the patient sample were diluted in assay buffer, acidified with $\mathrm{HCL}$ and then neutralized with $\mathrm{NaOH}$. Afterwards, the neutralized standards and samples were added to the antibodycoated (polyclonal) microlitre wells.

After the first incubation, the unbound sample material is removed by washing. Then a monoclonal mouse anti-TGF- $\beta 1$ antibody, a biotinilated anti-mouse IgG antibody and the Streptavidin-HRP Enzyme complex were incubated. An immune enzyme sandwich complex was formed. After incubation, the unbound conjugate was washed off. Having added the substrate solution, the intensity of colour developed was proportional to the concentration of TGF- $\beta 1$ in the patient's sample.

\section{Statistical analysis}

Sample size was calculated and data were coded and entered using the statistical package SPSS version 25. Data was summarized using mean and standard deviation for quantitative variables and frequencies (number of cases) and relative frequencies (percentages) for categorical variables. Comparison between both groups was done using independent sample $t$ test or Mann-Whitney rank sum test or chi-square when appropriate. Correlation between quantitative variables was done using Pearson's correlation coefficient, and $P$ values less than 0.05 were considered as statistically significant. 
Table 1 The demographic characteristic of the study population

\begin{tabular}{llll}
\hline Parameter & IIP group $(\boldsymbol{N}=30)$ & Control group $(\boldsymbol{N}=20)$ & $\boldsymbol{P}$ value \\
\hline Age (years) & $44(40-57)$ & $41.5(39.25-55.25)$ & $0.38^{\wedge \wedge}$ \\
Sex (female) & $17(56.67 \%)$ & $10(50 \%)$ & $0.82^{\#}$ \\
Smoking (No) & $21(70 \%)$ & $10(50 \%)$ & $0.25^{\#}$ \\
\hline
\end{tabular}

Numerical data normally distributed represented as mean \pm SD and data not normally distributed represented as median (Q1-Q3), categorical data as number (\%). Significant $P$ value: $<0.05$

IIP idiopathic interstitial pneumonia, $N$ number

${ }^{\wedge}$ Mann-Whitney rank sum test

${ }^{\#}$ Chi-square

\section{Results}

\section{Patients' characteristics}

Patients' demographic characteristics are shown in Table 1 . The study involved 30 patients and 20 healthy individuals as a control group.

The patients' group included 15 patients with IPF, 12 patients with NSIP, 2 patients with DIP and one patient with RB-ILD. There was no statistical difference between both the patients' group and the control group as regards the age, sex and the smoking habit.

Most of the patients had severe restrictive function $(n=17)$ (Fig. 1). Advanced grade of dyspnoea was present in ten patients (33.33\%) (Table 2). The mean distance of 6 -MWT was $148.67 \pm 116.49 \mathrm{~m}$.

\section{The arterial blood gases parameters}

The mean arterial oxygen pressure $\left(\mathrm{PaO}_{2}\right)$ was 46.53 $\mathrm{mmHg}$, the mean alveolar-arterial oxygen pressure $\left(\mathrm{PA}-\mathrm{aO}_{2}\right)$ difference was $51.07 \mathrm{mmHg}$ and there was a normal mean arterial carbon dioxide pressure. Room air arterial oxygen saturation $\left(\mathrm{SaO}_{2}\right)$ was $82 \%$ (Table 2).
Table 2 The clinical characteristics and $A B G_{S}$ of the patients' group

\begin{tabular}{|c|c|c|}
\hline Parameter & IIP group $(\boldsymbol{N}=30)$ & \\
\hline \multirow[t]{3}{*}{ The severity of the restriction } & Mild & $3(10 \%)$ \\
\hline & Moderate & 10 (33.33\%) \\
\hline & Severe & 17 (56.67\%) \\
\hline \multirow[t]{4}{*}{ Dyspnoea score (mMRC) } & 1 & $4(13.33 \%)$ \\
\hline & 2 & $7(23.33 \%)$ \\
\hline & 3 & $9(30)$ \\
\hline & 4 & $10(33.33)$ \\
\hline 6-MWD (meter) & $148.67 \pm 116.49$ & \\
\hline \multirow[t]{6}{*}{ The arterial blood gases } & $\mathrm{PH}$ & $7.42 \pm 0.05$ \\
\hline & $\mathrm{PaCO}_{2}(\mathrm{mmHg})$ & $42.13 \pm 10.59$ \\
\hline & $\mathrm{PaO}_{2}(\mathrm{mmHg})$ & $46.53 \pm 11.85$ \\
\hline & $\mathrm{HCO}_{3}(\mathrm{mEq} / \mathrm{L})$ & $26.63 \pm 6.30$ \\
\hline & $\mathrm{PA}-\mathrm{aO}_{2}$ difference & $51.07 \pm 14.63$ \\
\hline & $\mathrm{O}_{2}$ saturation $\%$ & $82 \% \pm 0.09$ \\
\hline
\end{tabular}

Data represented as number and percentage or mean \pm standard deviation mMRC modified medical research council of dyspnoea, 6-MWD 6-minute walks distance, $\mathrm{PH}$ logarithm of hydrogen ion, $\mathrm{PaO}_{2}$ arterial oxygen pressure, $\mathrm{PaCO}_{2}$ arterial carbon dioxide pressure, $\mathrm{HCO}_{3}$ bicarbonate, $\mathrm{SaO}_{2}$ arterial oxygen saturation, $\mathrm{PA}-a \mathrm{O}_{2}$ alveolar-arterial oxygen pressure difference

\section{Transforming growth factor- $\beta 1$}

The patients' group showed significant elevation of serum level of TGF- $\beta 1$ in comparison with the control group ( $P$ value $<0.001)$ (Table 3 ; Fig. 2 ).

It is worth to attention that the serum level of TGF- $\beta 1$ did not significantly differ in patients with IPF compared to patients with other forms of major IIP (mean $\pm \mathrm{SD}=$ $300 \pm 84.52$ versus $340 \pm 131.20 \mathrm{pg} / \mathrm{ml}, P$ value $=0.32$ )

Table 4 showed that there was an inverse negative correlation between the age and serum level of TGF- $\beta 1$ ( $r=$ $-0.39 ; P=0.03$ ) (Fig. 3a).

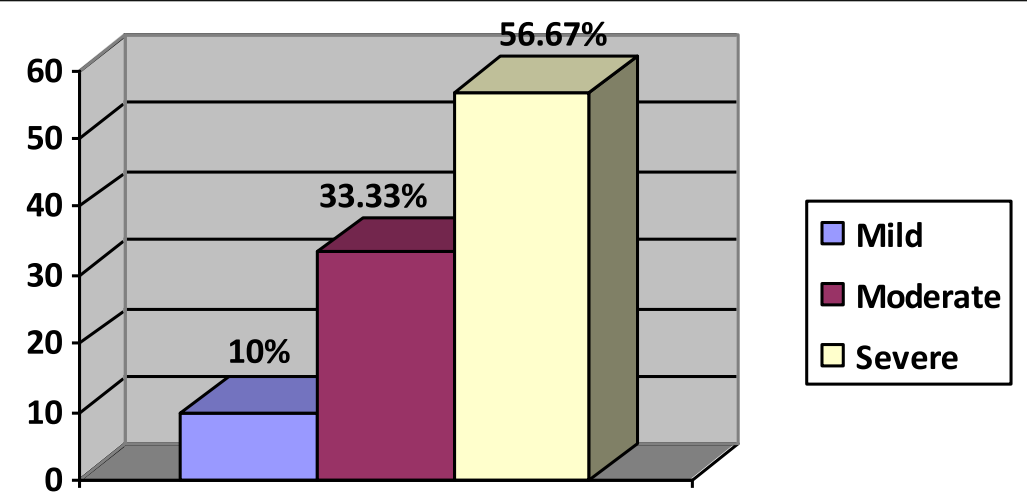

The severity of restriction \%

Fig. 1 The severity of restriction in the IIP group: mild, forced vital capacity (FVC) 60-80\%; moderate, FVC 40-59\%; and severe restriction, FVC less than $40 \%$ 
Table 3 Serum level of transforming growth factor $\beta 1$ in both groups

\begin{tabular}{llll}
\hline Variable & $\begin{array}{l}\text { II group }(\boldsymbol{n}=30) \\
\text { Median (IQR) }\end{array}$ & $\begin{array}{l}\text { Control group }(\boldsymbol{n}=20) \\
\text { Median (IQR) }\end{array}$ & $\boldsymbol{P}$ value \\
\hline TGF- $\boldsymbol{\beta} \mathbf{1}(\mathbf{p g} / \mathbf{m l}))$ & $300(250-400)$ & $100(100-100)$ & $<0.001^{\wedge \wedge}$
\end{tabular}

$P$ : considered significant if $<0.05$

IIP Idiopathic interstitial pneumonia, TGF- $\beta 1$ transforming growth factor beta1

${ }^{\wedge}$ Mann-Whitney rank sum test

There was an inverse non-significant correlation between the serum level of TGF- $\beta 1$ and the dyspnoea score $(r=-0.30, P=0.11)$ (Fig. $3 \mathrm{~b})$. However, there was a significant positive correlation between the serum level of TGF- $\beta 1$ and distance of 6 -MWT $(r=0.44 ; P=0.02)$ (Fig. 3c).

It was also found that there was a positive correlation between the serum level of TGF- $\beta 1$ and $\mathrm{PaO}_{2}$ and arterial oxygen saturation (Table 5; Fig. 3d).

\section{Discussion}

Interstitial lung disease (ILD) is a chronic condition with distressing dyspnoea, progressive worsening of exercise capacity and decreased life expectancy.

In the current study, almost all patients were presented with moderate to severe restriction. Advanced grade of dyspnoea was a feature of almost $33 \%$ of the patients. Hypoxaemia was the main functional abnormality in those patients (Table 2).

Impairment of exercise capacity is present early in the disease and carries a worse prognosis. Exercise limitation was observed among the studied patients that were detected by a reduced distance of 6-MWT (mean $\pm \mathrm{SD}=$ $148.67 \pm 116.49 \mathrm{~m}$ ) (Table 2), in comparison to the expected 6-MWD for these patients in this age category based on Enright and Sherrill, 1998 reference equation: for men, $6-\mathrm{MWD}=(7.57 \times$ height in $\mathrm{cm})-(5.02 \times$ age $)$
Table 4 Correlation between serum levels of TGF- $\beta 1$ with the clinical data

\begin{tabular}{lll}
\hline Variables & Serum TGF- $\beta 1$ & \\
\hline Age & $\boldsymbol{r}$ & -0.39 \\
& $\boldsymbol{P}$ & 0.03 \\
Dyspnoea score & $\boldsymbol{r}$ & -0.30 \\
& $\boldsymbol{P}$ & 0.11 \\
6-MWD & $\boldsymbol{r}$ & 0.44 \\
& $\boldsymbol{P}$ & 0.02 \\
\hline
\end{tabular}

$r$ : Pearson's correlation, the sign before $(r)$ represent the direction of correlation. $P$ represents the significance of the correlation. $P$ is considered significant if $<0.05$

- (1.76 $\times$ weight in $\mathrm{kg})-309 \mathrm{~m}$, and for women, 6MWD $=(2.11 \times$ height in $\mathrm{cm})-(2.29 \times$ weight in $\mathrm{kg})$ $-(5.78 \times$ age $)+667 \mathrm{~m}[8]$.

The importance of this test lies in being an independent predictor of mortality in IPF patients, where the presence of $6-\mathrm{MWD}<250 \mathrm{~m}$ carries a twofold increase in the risk of mortality as stated by du Bois and coworkers [9].

Idiopathic pulmonary fibrosis (IPF) is particularly important as it may progress rapidly in some patients to produce loss of lung function and may progress insidiously with the period of apparent symptomatic and physiological instability in others [10].

TGF- $\beta 1$ plays a key role in fibroblast homeostasis and is involved in disease states characterized by excessive fibrosis, such as pulmonary fibrosis $[11,12]$. It is one of the most potent inducer of extracellular matrix (ECM) production, including collagen and other matrix proteins [13]. TGF- $\beta 1$ has been shown to modulate micro RNA expression [14].

The main findings in our study were that the serum level of TGF- $\beta 1$ was significantly high in the patients' group,

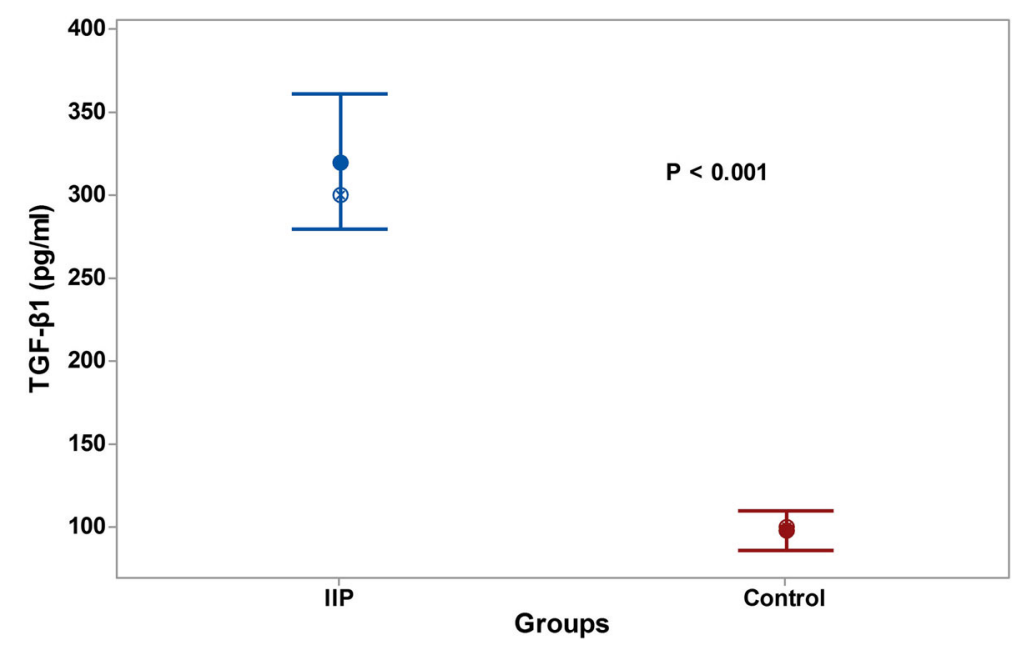

Fig. 2 The serum level of transforming growth factor $\beta 1$ in both groups 


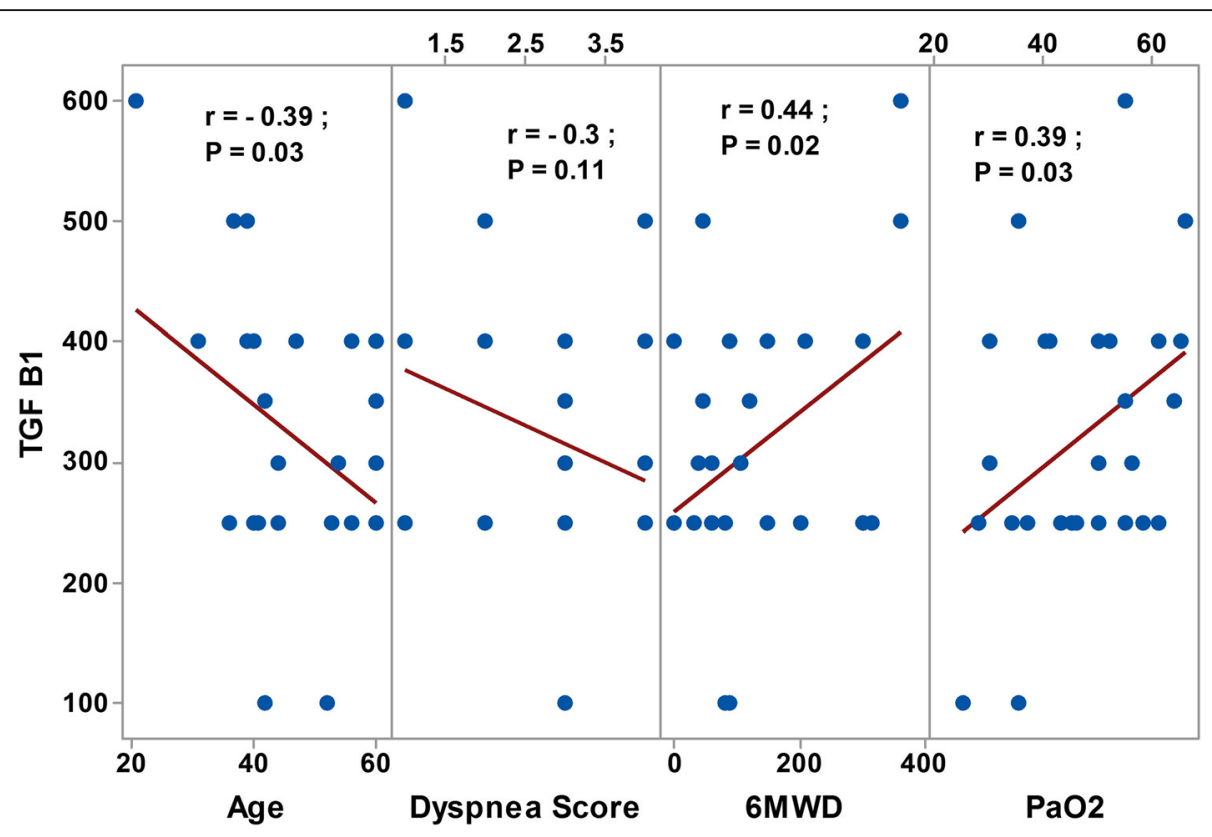

Fig. 3 Correlation between serum levels of TGF $\beta 1$ with the clinical data and $\mathrm{PaO}_{2}$ : a. Age. b. Dyspnea score. c. 6- MWD. d. $\mathrm{P}_{\mathrm{a}} \mathrm{O}_{2}$

relative to the healthy control group (Table 3; Fig. 2); besides, there was an inverse correlation between its serum level and dyspnoea score and a positive correlation with 6MWD and $\mathrm{PaO}_{2}$ (Table 4; Fig. 3) that may appear as a controversy and reflect its possible prognostic value.

A number of studies have shown that patients with IIP had a higher serum concentration of TGF- $\beta 1$ than healthy controls [15].

There was a significant negative correlation between TGF- $\beta 1$ and age (Table 4), which was in accordance to Okamoto and colleagues [16].

Table 5 Correlation between serum levels of TGF- $\beta 1$ and $A B G_{s}$

\begin{tabular}{lll}
\hline Variables & Serum TGF- $\beta 1$ & \\
\hline $\mathrm{PH}$ & $r$ & 0.35 \\
& $P$ & 0.06 \\
$\mathrm{PaCO}_{2}$ & $r$ & $0.22-$ \\
& $P$ & 0.23 \\
$\mathrm{PaO}_{2}$ & $r$ & 0.39 \\
& $P$ & 0.03 \\
$\mathrm{HCO}_{3}$ & $r$ & -0.15 \\
& $P$ & 0.42 \\
$\mathrm{PA} \mathrm{aO}_{2}$ difference & $r$ & -0.12 \\
& $P$ & 0.52 \\
$\mathrm{O}_{2}$ saturation (room air) & $r$ & 0.33 \\
& $P$ & 0.07
\end{tabular}

$r$ : Pearson's correlation, the sign before $(r)$ represents the direction of correlation. $P$ represents the significance of the correlation. $P$ is considered significant if $<0.05$
The significant positive correlation between the serum TGF- $\beta 1$ and 6-MWD was also observed in Heinemeier's study [17] who evaluated the influence of exercise on systemic and local TGF- $\beta 1$ levels, in the peri-tendon tissue sample. The outcome showed a significant increase in plasma TGF- $\beta 1$ which indicated a release of the cytokine in response to exercise. The positive relation with $\mathrm{PaO}_{2}$ and arterial oxygen saturation was not explained nor expected, yet this may be due to accumulation of the TGF- $\beta 1$ in tissues on the expense of the serum level in cases of tissue hypoxia (Table 5).

In the current study, the serum level of TGF- $\beta 1$ in IPF patients showed no significant difference from patients with other forms of major IIP that may be due to the limited number of patients.

\section{Conclusion}

Serum level of TGF- $\beta 1$ is elevated in patients with IIP and further larger studies are needed to evaluate its prognostic value.

\section{Abbreviations}

IIP: Idiopathic interstitial pneumonia; TGF- $\beta 1$ : Transforming growth factorbeta1; IPF: Idiopathic pulmonary fibrosis; 6-MWT: Six-minute walk test; $\mathrm{PaO}_{2}$ : Arterial oxygen pressure; ILD: Interstitial lung disease; mMRC: Modified Medical Research Council scale; TLC: Total lung capacity; FVC: Forced vital capacity; FEV1: Forced expiratory volume in the first second; FEF: Forced expiratory flow; $\mathrm{HRCT}$ : High-resolution computed tomography; $\mathrm{ABG}_{\mathrm{s}}$ : Arterial blood gases; $\mathrm{PaCO}_{2}$ : Arterial carbon dioxide pressure; $\mathrm{SaO}_{2}$ : Arterial oxygen saturation; $\mathrm{PA}_{-}-\mathrm{aO}_{2}$ : Alveolar arterial oxygen pressure difference; ELISA: Enzyme-linked immunosorbent assay; NSIP: Nonspecific interstitial pneumonia; DIP: Desquamative interstitial pneumonia; RB-ILD: Respiratory bronchiolitis-associated interstitial lung disease; ECM: Extracellular matrix 


\section{Acknowledgements}

All authors are thankful to the residents at the Chest Department who helped in the collection of data.

\section{Authors' contributions}

Concept of the study: MZ, RK, IB and SS. Data collection: KA. Data analysis: $M Z, R K, I B, S S$ and KA. Writing the original draft: RK, SS, IB and KA. The author(s) read and approved the final manuscript.

\section{Funding}

Not applicable.

\section{Availability of data and materials}

Not applicable.

\section{Ethics approval and consent to participate}

The ethical committee of the Faculty of Medicine, Cairo University, approved the study (the committee's reference number is not available) and a written informed consent was obtained from each participant.

\section{Consent for publication}

Not applicable.

\section{Competing interests}

Not applicable.

\section{Author details}

${ }^{1}$ Department of Chest Diseases, Faculty of Medicine, Cairo University, Cairo, Egypt. ${ }^{2}$ Department of Pharmaceutical Biotechnology, Faculty of Biotechnology, Misr University of Science and Technology, Giza, Egypt. ${ }^{3}$ Department of Chest Diseases, Faculty of Medicine, JUBA University, Juba, Sudan.

Received: 13 June 2020 Accepted: 30 July 2020

Published online: 18 August 2020

\section{References}

1. Travis WD, King JR, Bateman ED, Lynch DA, Center D, Colby TV (2002) American thoracic society/European respiratory society international multidisciplinary consensus classification of the Idiopathic interstitial pneumonia. Am J Respir Crit Care Med 165(2):277-304. https://doi.org/10. 1164/ajrccm.165.2.ats01

2. Travis WD, Costabel U, Hansell DM, King TE Jr, Lynch DA, Nicholson AG et al (2013) An official American Thoracic Society/European Respiratory Society statement: update of the international multidisciplinary classification of the idiopathic interstitial pneumonias. Am J Respir Crit Care Med 188(6):733-748

3. Fernondez IE, Ericklberg O (2012) The impact of TGF-Beta on lung fibrosis. From targeting to biomarkers. Proc Am Thorac Soc 9(3):111-116

4. Agassandian M, Tedrow JR, Sembrat J, Kass DJ, Zhang Y, Goncharova EA et al (2015) VCAM-1 is a TGF- $\beta 1$ inducible gene up regulated in idiopathic pulmonary fibrosis. Cell signal Dec 27(12):2467-2473

5. Saito A, Horie M, Nagase T (2018) TGF- 31 signaling in lung health and diseases. Int J Mol Sci 19(8):2460

6. Pellegrino R, Viegi G, Brusasco V, Crapo RO, Burgos F, Casaburi R et al (2005) Interpretative strategies for lung function tests. Eur Respir J 26(5):948-968

7. American Thoracic Society (2002) ATS statement: guidelines for the six minute walk test. Am J Respir Crit Care Med. 166(1):111-117

8. PL E, Sherrill DL (1998) Reference equation for the six-minute walk in healthy adults. Am J Respir Crit Care Med 58:1384-1387

9. Du Bois RM, Albera C, Brandford WZ, Costable U, Leff A, Paul W et al (2014) Six minute walk distance is an independent predictor of mortality in patients with idiopathic pulmonary fibrosis. Eur Resp J 43(5):1421-1429

10. Harari S, Caminati A (2010) IPF: new insight on pathogenesis and treatment. Allergy 65:537-553

11. Papakonstantinuou E, Roth M, Tamm M, Eickelberg O, Perruchoud AP, Karakiulakis G (2002) Hypoxia differently enhances the effects of transforming growth -beta isoform in the synthesis and secretion of glycosaminoglycans by human lung fibroblasts. J Pharmacol Exp Ther 301(3):830-837

12. Papakonstantinou E, Aletars A, Roth M, Tamm M, Karakiulakis M (2003) Hypoxia modulates the effects of transforming growth factor-beta isoforms on Matrix-transformation by primary human lung fibroblasts. Cytokine 24(12):25-35

13. Yue $X$, Shan B, Lasky JA (2010) TGF- $\beta 1$ : Titan of lung fibrogenesis. Curr Enzym Inhibitor 6(2):10.2174/10067

14. Pottier N, Maurin T, Chevalier B, Puisségur MP, Lebrigand K, RobbeSermesant K et al (2009) Identification of keratinocyte growth factor as a target of microRNA-155 in lung fibroblasts: implication in epithelialmesenchymal interactions. PLoS One 4(8):e6718

15. Grainger D, Healthcote $K$, Chaiano M, Snieder H, Kemp J, Metcalfe $N$ et al (1999) Genetic control of the circulating concentration of transforming growth factor type1. Hum Mol Genet 8(1):93-97

16. Okamoto Y, Gotoh Y, Uemura O, Tanaka S, Ando T, Nishida M (2005) Agedependent decrease in serum transforming growth factor (TGF)-beta 1 in healthy Japanese individuals; population study of serum TGF-beta 1 level in Japanese. Dis Markers 21(2):71-74

17. Heinemeier K, Henning L, Olesen JL, Kjaer M (2003) Role of TGF- $\beta 1$ in relation to collagen synthesis in human tendentious tissue. J Appl Physiol 95(6):2390-2397

\section{Publisher's Note}

Springer Nature remains neutral with regard to jurisdictional claims in published maps and institutional affiliations.

\section{Submit your manuscript to a SpringerOpen ${ }^{\circ}$ journal and benefit from:}

- Convenient online submission

- Rigorous peer review

- Open access: articles freely available online

- High visibility within the field

- Retaining the copyright to your article

Submit your next manuscript at $\boldsymbol{\nabla}$ springeropen.com 